\title{
Optimization of Cultural Parameters for Cellulase Enzyme Production from Fungi Species Isolated From Degradation Corn Cob
}

\author{
Bamigboye, O. O. \\ Department of Biology Emmanuel Alayande College of Education, Oyo.
}

\begin{abstract}
Cellulalytic fungi synthesize cellulose enzyme for biodegradation of cellulose. This depends on various condition which include the source $f$ isolation. This study was designed to determine the optimum condition necessary for cellulose production by fungi.

Cellulose activities at different temperatures, $p H$ and nitrogen sources by Rhizopus oryzae Aspergillus niger; A. flams, $P$. expansum and A. oryzae in liquid medium was studied and cellulose enzyme assay carried out by dinitrosalicylic acid method.

All the fungal isolates have their highest cellulose activity at $40^{\circ} \mathrm{c}$ except Penicillium expansum whose highest value of $1.28 \mathrm{mg} / \mathrm{ml}$ was obtained at $32^{\circ} \mathrm{c}$. Cellulase produced $6 \mathrm{~m}$ was found to be highest in all the isolate at $\mathrm{pH} 4.0$ exception P expansum which occur at $\mathrm{pH} 5.5(1.21 \mathrm{mg} / \mathrm{ml})$. The highest value e1.45 $\mathrm{mg} / \mathrm{ml}$ was obtained in A niger. Highest cellulose activity for A. niger, A. oryzae \& P. expansum occurred in peptone.

The study shows the need to determine the best physiological condition that allow for the optimal cellulose activity of fungal isolate. This will enhance their enzyme production.
\end{abstract}

Key Word: Cellulase, fungi, $\mathrm{pH}$, Nitrogen, temperature

\section{Introduction}

Cellulases a cosorfulm of free enzymes which comprises of enchoglucanase ( $\beta$ 1-4-D glucan-4glucanolydrolase EC 3.2.1.4, carboxymethyl cellulalse, EC) Exoglucanase ( $\beta$-1,4-D glucan-4-glucahydrolase EC allobiohydrolase, $\mathrm{CBH}$ ) and cellobiases ( $\beta$-d-glucoside glucohydrolase, EC 3.2.1.21, $\beta$-I, 4-D-glucosidase) which are found in many of the 57 glycosyl hydrolase families. (Siddigui et al. 2000) cellulose is the enzyme that hydrolyzes the $\beta-1-4$ glycosidic bonds I enzyme.

Fungi are the most prominent cellulose producing microorganism (Immanuel et al 2007). Although a large number of microorganisms are capable of degrading cellulose, only a few of these produce significant quantities of cell free enzyme capable of completely hydrolyzing crystalline cellulose (Kooniinok, 2005). The need to optimize the cultural condition for igmnt maximum production of the enzyme is therefore essential.

\section{Materials and Method}

All chemicals used were reagent grade obtained from May \& Baker and Sigma - Aldrich chemical company India. The fungi, Aspergillus niger, Rhizopus oryzae, Aspergilus oryzae, Penicillum expansum and Aspergillus flavus used in this study were isolated from degrading corn cob on Potato Dextrose agar and yeast extract agar. Pure cultures obtained were identified by conventional test and maintained on PDA slants.

The five fungal isolates were separately grown and tested for production of cellulose in submerged culture in a chemically defined medium composed of $\mathrm{KH}_{\mathrm{z}} \mathrm{P} 0 \mu\left(1 \mathrm{gl}^{-1}\right) \mathrm{MgS}_{0} 47 \mathrm{H}_{\mathrm{z}} 0\left(0.5 \mathrm{gl}^{-1}\right)$ yeast extract $\left(1 \mathrm{gl}^{-1}\right)$ $\mathrm{Ccl}_{2} 2 \mathrm{H}_{2} 0 \mathrm{Co}_{1} 14 \mathrm{gl}^{-1}$ ) carboxymethyl cellulose $10 \mathrm{~g}$ and thiavaine $\left.0.0025 \mathrm{gl}^{-1}\right)$. The cultures were grown at $27^{0} \mathrm{c}$ for 28 days, culture broth was sampled at different days during growth to determine enzyme productivity by carboxymethyl hydrolysis.

\section{Enzyme assay}

Cellulose activity was assayed by the determination of reducing sugar released from carboxymethyl cellulose (CMC). After growth had been allowed to proceed for the required length of time at the required temperature, the cultures were filtered through sintered glass crucibles and the cellulolytic activity of the filterates was determined using the method of Reese and Mandels (1963). The assay medium was 0.55\% caroxymethyl cellulose (CMC) in $0.55 \mathrm{~m}$ acetate buffer $(\mathrm{pH} 5.5)$ and $9 \mathrm{ml}$ of this were incubated with $1 \mathrm{ml}$ of the fungus filterate for 1 hour at $37^{\circ} \mathrm{c}$. Filterates of the uninoculated control was also obtained and similarly assayed. To estimate the amount of reducing sugars released, $1 \mathrm{ml}$ of dinitrosalicylic acid (DNSA) reagent was added to $1 \mathrm{ml}$ of the filterate $-\mathrm{CMC}$ reaction mixture and the absorbance was determined at $540 \mathrm{~mm}$ using an SP 600 spectrophotometer.

The absorbance of standard aqueous solution of D-glucose at various concentrations (0-10mg per $\mathrm{ml})$ 
was determined and used to construct a graph of percentage absorbance as related to mg of glucose per ml. The amount of reducing sugar produced by $1 \mathrm{ml}$ of bacteria filterate from the CMC assay medium was calculated form this graph. Cellulolytic activity of the filterates was then expressed in term of the amount of total reducing sugars (RS) per ml.

\section{Effect of Temperature on Cellulase Activity}

Bottles of the chemically defined medium were inoculated and incubated at 28,32 and $40^{\circ} \mathrm{C}$. These were subsequently filtered and cellulose activity of the filtrate were determined at $0,4,7,14,21$ and 28 days.

\section{Effect pH on Celulase Activity}

Some bottles of the chemically defined medium were inoculated and incubated at $27^{\circ} \mathrm{C}$. Prior to inoculation the $\mathrm{pH}$ of the media was adjusted to $\mathrm{pH} 4.0,5.5$ and 7 . The samples were filtered at $0,4,7,14,21$ and 28 days and cellulose activity at the afferent $\mathrm{pH}$ was determined.

\section{Effect of Nitrogen Source on Cellulase Activity}

The organisms were cultivated in the chemically defined media containing $1 \%$ carboxymethyl cellulose and supplemented with different Nitrogen sources of $1 \%(\mathrm{w} / \mathrm{v})$. The nitrogen sources used include yeast extract, peptone, urea, $\left(\mathrm{NH}_{4}\right)_{2} \mathrm{SO}_{4}$ and $\mathrm{NaNO}_{2}$. These were incubated at $27^{\circ} \mathrm{C}$ and cellulose activity of the filtrate were determined at $0,4,7,14,21$ and 28 days in the different Nitrogen sources.

\section{Result and Discussion}

Cellulose activity under different physiological conditions by Rhozopus oryzae, Aspergillus niger, A flavus, Penicillum expansum and A. oryzae was studied.

All the fungal isolates showed cellulase activity, fungi of the geura Aspergillus and Penicillium have been reported as good cellulase producers (Milala et al., 2005, Hoffinem ad Wood, 1985, Abo State et al., 2010).

The result of cellulase activity at different temperatures by the fungal isolates is shown in figure 1 . Cellulase activity was found to be highest in $40^{\circ} \mathrm{c}$ in $A$ niger with a value of $1.32 \mathrm{mg} / \mathrm{ml}$. Rhizopus oryzae at $32^{\circ} \mathrm{c}$ in day 14. All the fungal isolates had their highest reducing sugar production at $40^{\circ} \mathrm{C}$ except Penicillum expansum with the highest value of $1.28 \mathrm{mg} / \mathrm{ml}$ on day 14 . This agreed with Immaneul et al., (2007) who reported the optimum temperature for cellulase enzyme production by $A$. niger \& A. fungatus at $40^{\circ} \mathrm{C}$.

The optimum $\mathrm{pH}$ for A niger, A flavus and Rhizopus oryzae was $\mathrm{pH} 4.0$ as shown in figure 2 while $P$ expansum and Aspergillus oryzae was at pH 5.5. Akiba et al., (1995) reported that cellulase production was high at $\mathrm{pH} 4$ and 4.5 by $A$. niger optimum activity for $A$. niger, A oryzae and $P$ expansum occurred in peptone as seen in Figure $3^{a} \& b$. This correlates with the result of Guatam et al., (2011) who reported that peptone enhanced the production of cellulase by A niger on solid municipal waste residue.

\section{Cellulase Activity at $28^{\circ} \mathrm{C}$}

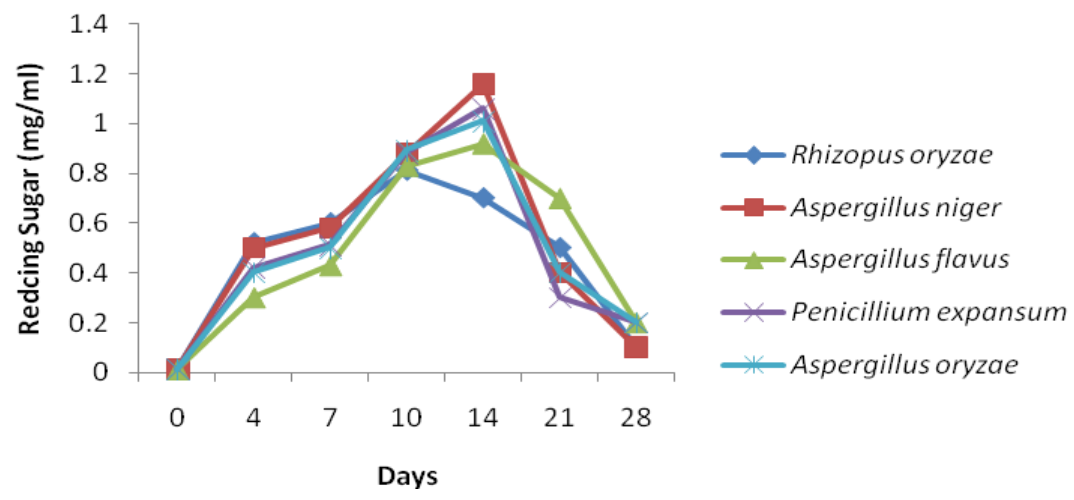




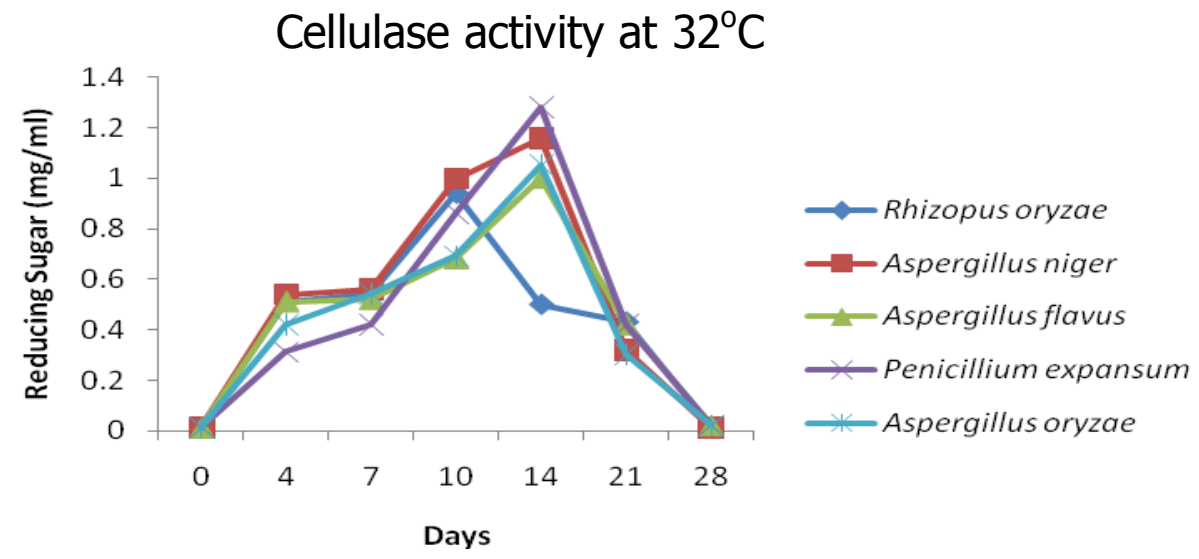

Cellulase activity at $40^{\circ} \mathrm{C}$

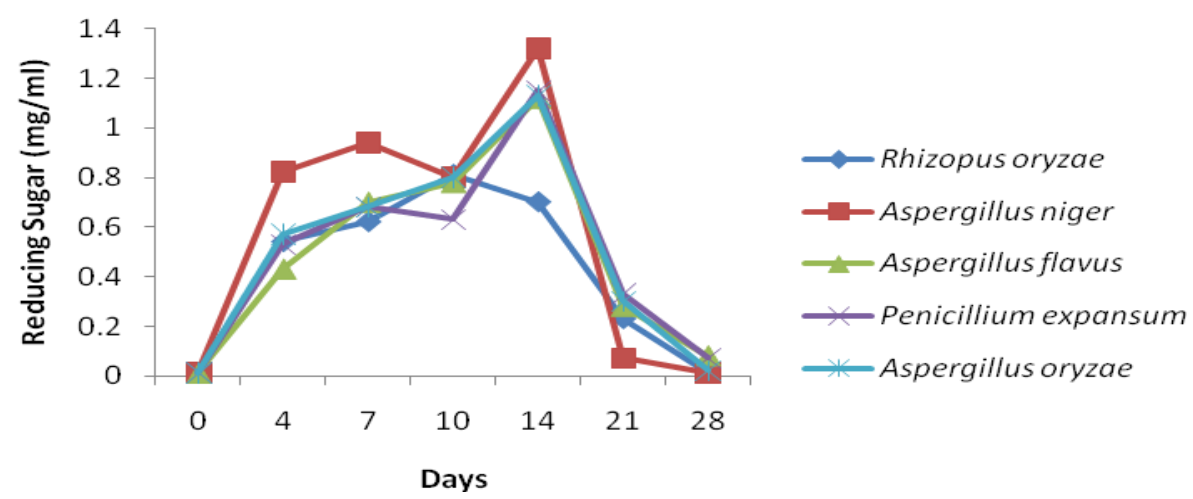

Fig.6: Effect of temperature on the cellulase production by fungal isolates

\section{pH 4.0}

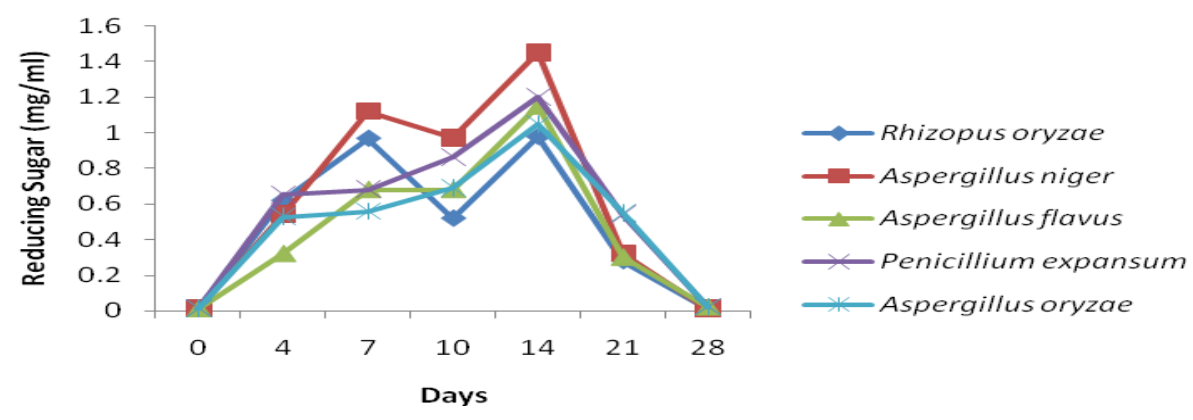

pH 5.5

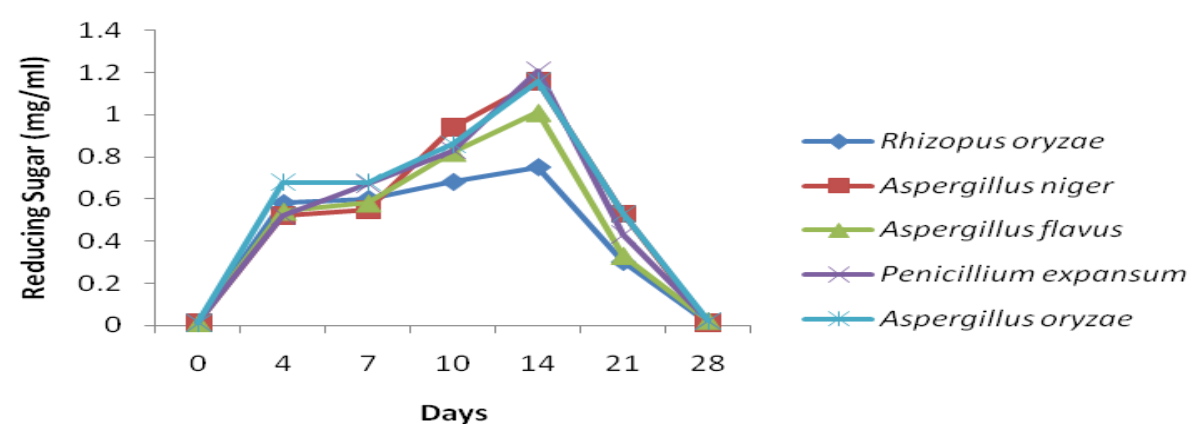




\section{pH 7.0}

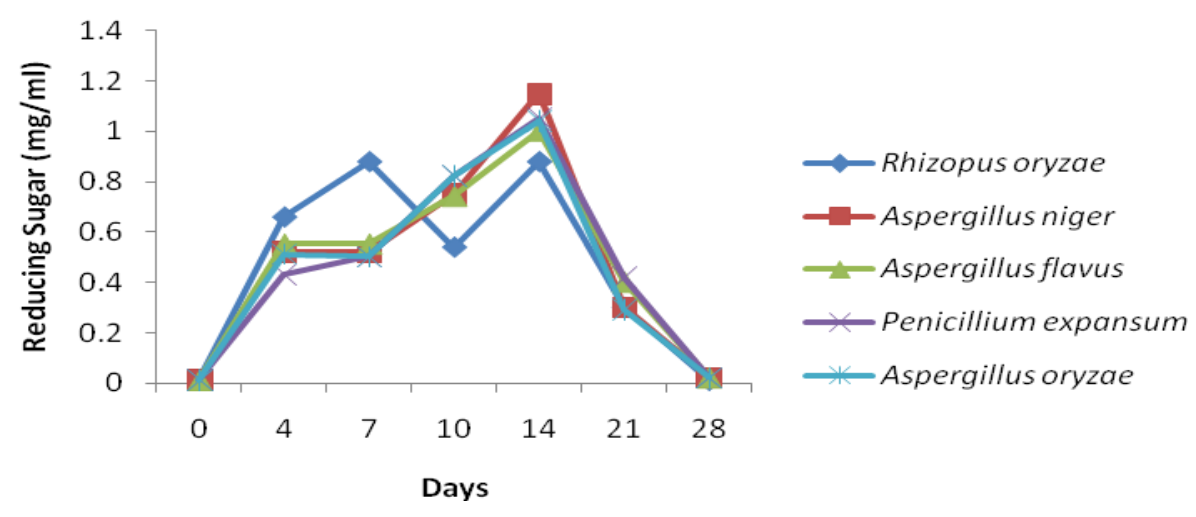

Fig.7: Effect of $\mathrm{pH}$ on the cellulase production by fungal isolates

Yeast Extract
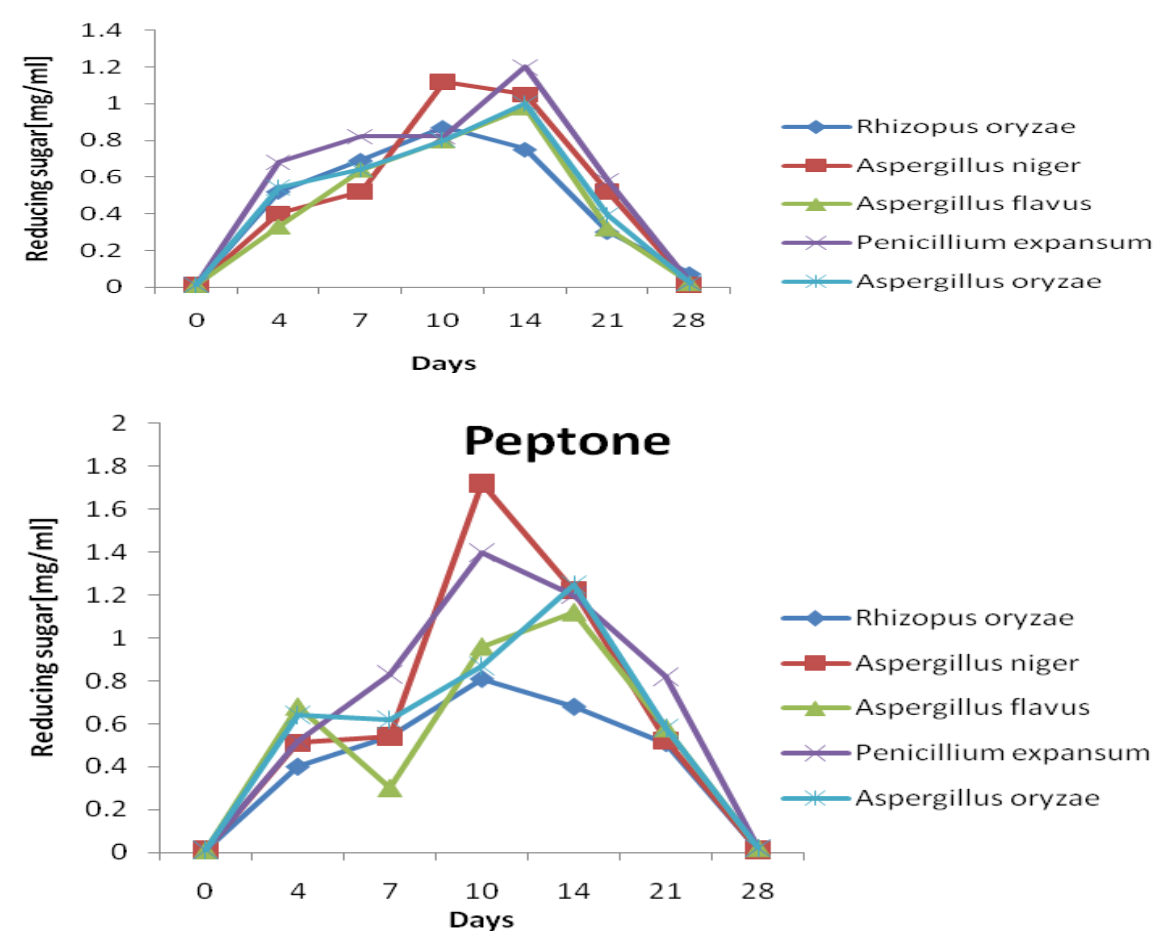

$\mathrm{NH}_{4} \mathrm{Cl}$

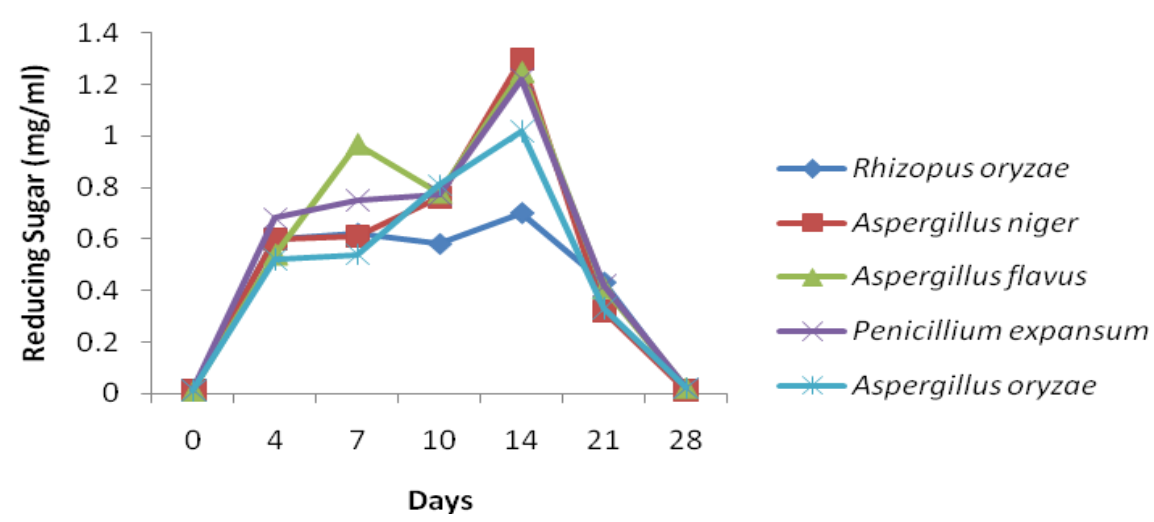

Fig.8a:

Effect of different nitrogen sources on cellulase production by fungal isolates 


\section{Urea}
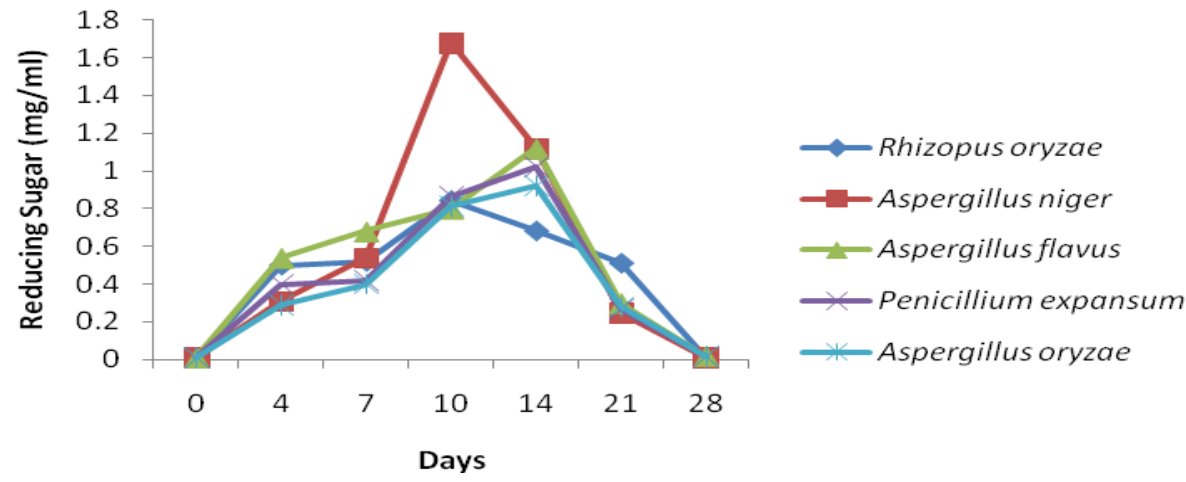

$\mathrm{NaNO}_{2}$

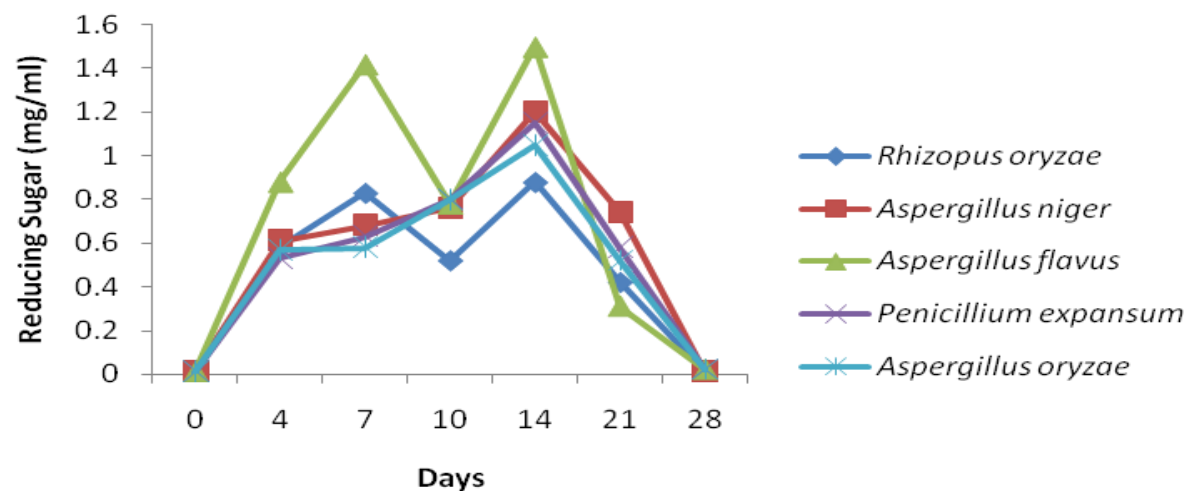

Fig.8b:Effect of different nitrogen sources on cellulase production by fungi isolates

\section{References}

[1]. Abo-State, M.A.M., Hammad, A.E., Selin M. and Gannam R.B. 2010. Enhanced production of cellulases by Aspergillus sp on agricultural wastes by solid state fermentation. American - Eurasian Journal of Agricultural \& Environmental Science. $402-410$

[2]. Akiba, S., Kimura, K. and Kumugal, H. 1995. Purification and characterization of protein resistant cellulase from Aspergillus niger. Journal of Fermentation Bioengineering 79: 125 - 130

[3]. Gautam, S.P., Bundela, R.S., Pandey, A.K., Khan, J. Awashi, M.K. and Sarsaiya, S. 2011. Optimization for the production of cellulose enzyme from municipal solid waste residue by two novel cellulolytic Fungi Biotechnology Research Tnternational 2011: 8 .

[4]. Hoffman, R. M and Wood, T.M. 1985. Isolation and partial characterization of a mutant Penicillium for the saccharification of straw. Biotechnology. Bioengineering 27: 81-85.

[5]. Immanuel, G., Akila Bhagavath, C. M. Iyapppa Raj, P., Essakking, P. and Palavessam A. 2007. Production and partial purification of cellulase by Aspergillus niger and A. fumigatus fermented in coir waste and saw dust. Internet Journal for Microbiology 3:1 - 17 .

[6]. Koomnok, C. 2005. Selection of cellulose producing thermophilic fungi. $31^{\text {st }}$ congress on Science and Technology of Thailand.

[7]. Milala, M.A., Shugaba, A., Gidado, A., Ene, A.C. and Wafar, J.A. 2005. Studies on the use of aricultural wastes for cellulase enzyme production by Aspergillus niger. Research Journal of Agriculture and biological Sciences 1. 4: 323-325.

[8]. Nishida, Y., Suzuki K.I., Kumayai, Y., Tanaka, H., Inove, A. and Ojima, T. 2007. Isolation and primary structure of a cellulose from the Japanese sea urchin. Strongylocentrotus nudus. Biochime. 1-10.

[9]. Siddigni, K.S., Saqib, A.A.N., Rashid, M.H. and Rajoka M.I. (2000). Carboxyl group modification significantly altered the kinetic of purified carboxymethylcellulase from Aspergillus niger. Enzyme and Microbial Technology Vol 27, No 7, Pp 467-474. 